\title{
2. Guthadjaka and Garngulkpuy: Indigenous women leaders in Yolngu, Australia-wide and international contexts
}

\author{
Gwenda Baker, ${ }^{1}$ Joanne Garngulkpuy² and \\ Kathy Guthadjaka ${ }^{3}$
}

This chapter explores the extraordinary growth in political leadership over the past 30 years among Indigenous women from a remote community. It is representative of a wider Australian phenomenon: the intense participation in democratic affairs by Indigenous women. These are two women from among many more: there are others who are participating at a similar level in this and other communities in the Northern Territory and elsewhere within Australia.

Guthadjaka and Garngulkpuy are two Yolngu women leaders from Elcho Island in the Northern Territory, a small island $500 \mathrm{~km}$ north-east of Darwin. Geographically isolated, they occupy a difficult space in leadership and democratic action due to their position between two worlds: the Yolngu world and the mainstream Australian world. They have to remain true to their connections to clan and country while working with the wider political and intellectual worlds within Australia and overseas.

Jackie Huggins explains that for an Indigenous leader, '[l]eadership means that you need to respect differences of views and start from where people are at not where you would want them to be. The trick is to listen, listen, listen, and then act. ${ }^{4}$ Both Guthadjaka and Garngulkpuy refer frequently with their elders, raising each individual issue before a consensus is reached. They speak for the community, not themselves. Their leadership is different in the ways that Amanda Sinclair identifies as less ego-driven, more spiritual, with different sources of power and responsibility. ${ }^{5}$ Ego is often set aside to respect others and their relationships. The work of Guthadjaka and Garygulkpuy as community leaders involves extraordinary intellectual and spiritual demands.

1 Monash University.

2 Yalu Marngithinyaraw Indigenous Corporation.

Charles Darwin University.

4 Jackie Huggins, 'Indigenous Women and Leadership - A Personal Reflection', Indigenous Law Bulletin 6(1) (2004): 3 .

5 Amanda Sinclair, Leadership for the Disillusioned: Moving Beyond Myths and Heroes to Leading that Liberates (Sydney: Allen \& Unwin, 2007), 145-68. 
Relationships with white powerbrokers are often quite fraught and problematic. Guthadjaka explained to Gwenda that within Yolngu groups, differences of opinion are managed through meetings and consensus. Problems are often triggered in public meetings by white people in control of town services when they select Yolngu leaders to speak, rather than ensuring all participants are empowered to voice their opinions. This can cause animosity between those chosen and those who feel they are denied the opportunity of participating. ${ }^{6}$

Guthadjaka and Garngulkpuy are constantly engaged in the processes necessary to reach a culturally acceptable position; and their job as leaders is to both suggest new directions and enact the decisions of the community. As Yolngu women working within both Yolngu and white cultural worlds, Guthadjaka and Garngulkpuy must decode and decipher what the Western world is saying and doing, examine it in relation to the epistemology of the Yolngu world and consult with their elders for direction. They must then explain it to the rest of the community and discuss its implications. Finally, they will argue an agreed Yolngu position to other Australians and the world.

In their leadership there are two clear spiritual sources: the Yolngu world and Christian teachings brought by the missionaries. Guthadjaka and Garngulkpuy operate within the influence of both these traditions. In this chapter, Guthadjaka is more specific about how her Christian beliefs underpin her leadership and work. Garngulkpuy is concerned more with establishing the importance of the spiritual connections to the land and between people in the Yolngu world. Both see themselves as operating with the direction of spiritually based interconnections between people, land and belief systems.

Guthadjaka and Garngulkpuy have been pivotal in promoting a wider level of political inquiry and activity within their communities. The two questions on governance they articulate relate to the past, present and future of these communities: how did we get to this point, and what are we going to do about the future of our children? This is a theme that is echoed in the wide range of interviews Gwenda and Garngulkpuy recently completed at Galiwin'ku. They also ask: 'How do we get people to listen to us?'

This chapter explores the leadership of Guthadjaka and Garngulkpuy as they seek to answer these questions. It will follow their personal dreams and enterprises, their local, national and international connections. Guthadjaka and Garngulkpuy have made significant changes in their lives to follow their vision, to develop plans that will benefit the education and welfare of children.

6 Private conversations between Gwenda and Guthadjaka, 2011 and 2012. 


\section{Guthadjaka and Garngulkpuy}

Guthadjaka and Garngulkpuy trained and worked as teachers within the NT school system before setting out to pursue their dreams for a better life for the children. Both have interacted with university-orientated teaching and learning systems, participated in numerous research activities and promoted Yolngu leadership and value systems.

Both women were chosen by their fathers to become leaders in their clans. The recruitment of daughters to fulfil these roles is a relatively new development over the past 30 years. Women have grown in the belief in their personal powers and have taken up education opportunities and leadership roles within their communities. The fathers have recognised this growth and come slowly to the decision that women may be the best people to take over clan leadership roles. At first, they had to decide if their daughters were knowledgeable in clan matters and committed to carrying out these roles. Garngulkpuy talked to me about how she questioned her father about clan matters and he asked her about her understanding of important ideas and concepts. Gradually, as he decided that she was perceptive and keen to learn, he taught her important knowledge about origins, storylines and processes. Both women have developed the skills to successfully lead and mediate between clans. They seek and receive counsel and guidance from their elders and participate fully in the processes of living a Yolngu life.

All clans have connections to other clans and other people. These are fundamental to the storylines of the Yolngu and all Indigenous people. Kathy Guthadjaka is Warramirri; Joanne Garngulkpuy is Wangurri. Warramirri and Wangurri are particularly close clans. Both clans need each other to carry out functions within the Yolngu world, to make relationships and society strong. Garngulkpuy explained the relationship in this way: 'Warramirri plants the seeds which Wangurri water to make the seeds grow.' ${ }^{7}$ Guthadjaka also talks about planting and growing seed.

Warramirri and Wangurri are both Yirritja, one of the two groups or moieties that complement each other in the Yolngu world. The other moiety is Dhuwa. The members of each moiety have roles and responsibilities in society, and people marry across these two moieties. Guthadjaka is Mari or grandmother to Garngulkpuy in relationship terms. Mari is the most important person within the groups of people who surround the individual in relationships within the clan system. Mari nurtures, gives advice, makes decisions and guides.

7 Private conversation between Gwenda and Guthadjaka, 11 October 2011. 
Guthadjaka and Garngulkpuy through similar processes are shaping a Yolngu version of leadership in society. Their concentration is on Yolngu processes and what it means to be a Yolngu woman leader. We have concentrated on the Yolngu world, the words and the philosophies of the women, not on Western theoretical models.

Both women work to make connections with other women and groups of people within Australia and other societies. They hope there will be wider meanings and applications for Yolngu constructions of leadership and participation in a democratic society.

\section{Kathy Guthadjaka}

Kathy Guthadjaka is a Gatjirrk Warramirri woman. She lives at Gäwa, at the northernmost part of Elcho Island. She grew up on the mission on Elcho Island. When Gwenda interviewed her in 2011, Guthadjaka told Gwenda she wanted to be a teacher but she was not particularly interested in school and did not get the grades she needed. After working in several jobs, she began working at the school as a teaching assistant, caught up on her studies and completed an associate diploma in teaching at Batchelor College. ${ }^{8}$

Guthadjaka has spent her life learning in both the Yolngu and the Western worlds, and communicating between the two. Very early in her teaching career, she began reaching out from her tiny remote world to the international world. She travelled to Bali and Java to look at Christian schools, and when she graduated she went as an exchange teacher to Canada to schools in the remote villages in Yellowknife. In her words: 'I didn't know where I was going or what I was doing. ${ }^{9}$ On her return from Canada, Guthadjaka worked at Shepherdson College, the main school on Elcho Island, working up to a grade two teacher. She then taught as a homeland teacher at small outlying settlements.

Guthadjaka's story is also about Gäwa, a Warramirri homeland at the northernmost part of Elcho Island. In 1985 her father, Ngulpurray, made the decision to move his family to Gäwa, in response to the growing problems in the township at Galiwin'ku. Guthadjaka's first trip back to Gäwa with the 'old man' was by boat, as there was otherwise only a bush track. The abundance of wild food-oysters, crayfish and wild honey — was an immediate attraction to

8 Kathy Guthadjaka, Interview with Gwenda Baker, Galiwin'ku, 21 June 2011.

9 Ibid. 
the place. They surveyed the area of a traditional ceremonial and meeting place and then decided to move slightly east to a bay offering better boat access and living conditions in the wet season. ${ }^{10}$

Ngulpurray asked his daughter Guthadjaka, by this time an experienced teacher, to help lead the people back so the children could live a better life there. Initially a group of 26 men and women and children cut a road to Gäwa by hand, with axes, shovels and fire. Many trips followed, and Guthadjaka began making plans to establish a school at Gäwa.

Guthadjaka said: 'When I went to [the] education [department] to set [it] up I thought it would be easy, because I was qualified.'11 What Guthadjaka was offered, however, was far from her vision of a school for Gäwa. She was offered a 'Homeland Learning Centre not a proper school. A proper school would get everything and we would get rubbish, maybe tables and chairs left over.' ${ }^{12}$ Guthadjaka goes back to the imagery of planting seeds: 'Missionaries were like seed planters, planting a vision. Government has no vision, that's why people are perishing, because there is no common vision for the people. ${ }^{\prime 3}$ Guthadjaka believes that ' $[\mathrm{i}] \mathrm{f}$ a child gets a good education in their own place and has a good understanding of their own place they will be successful when they step into the world'. ${ }^{14}$

To obtain funding from the NT Government for a Homeland Learning Centre a community must provide its own buildings and an unpaid teacher for a minimum of six months. If the attendance figures are maintained during that period, it might be recognised as a school. In 1991 Guthadjaka took six months' leave without pay from Shepherdson College to teach full-time at Gäwa, teaching under a tarpaulin, near the beach. The only contribution from the NT Government was for books and pencils, second-hand desks and secondhand chairs (never enough, so most children sat on the ground). In 1992 the NT Government provided $\$ 1,500$ for a new tarp for the school.

Anthropologist Ian McIntosh graphically described the system of discrimination operating in NT schools. He noted the inequities of the two systems:

Gäwa and other Homeland Learning Centers were denied any of the \$19 million commonwealth government funding for computers, satellite connection, printers and access to distance learning that was to provide

10 Ibid. Also Ian McIntosh, ‘Build a Future for Our Children: A Case Study of Institutional Discrimination in the Northern Territory of Australia', July 2009, http://www.culturalsurvival.org.au/docs/Case\%20Study\% 20 -\%20Building $\% 20$ a $\% 20$ Future $\% 20$ for $\% 20$ our $\% 20$ children.pdf.

11 Kathy Guthadjaka, Interview, 21 June 2011.

12 Ibid

13 Ibid.

14 'This is Gotha's Vision' from Gäwa Christian School pamphlet. 
for every remote school and 66 cattle stations across Australia. In 2002, ten years after its commencement, the Gäwa Homeland Learning Center had no toilet, running water, power, fax, computer, photocopier or other commonly supplied school equipment. ${ }^{15}$

After one year, Guthadjaka asked for but was refused permission to remain at the Gäwa school as a permanent teacher. She resumed her job at Shepherdson College at Galiwin'ku and became the homeland visiting teacher at Gäwa. From the beginning under Guthadjaka's tutelage, the school was successful. 'Within the first years six students had gone on to successfully complete their HSC [Higher School Certificate]. ${ }^{\prime 6}$ Despite this success, the residents at Gäwa were no closer to their dream of a locally run, properly resourced school. They built new school buildings with a $\$ 15,000$ contribution from the NT Government. For 10 years, there were no other funds for infrastructure.

This was a difficult time for Guthadjaka and her vision. After years of petitioning government authorities, Guthadjaka and the community at Gäwa decided to ask the NT Christian School Association to take over the running of the school. For Guthadjaka, to hand over the school was devastating, but there seemed to be no other solution. In 2003 Gäwa was granted independent school status. As McIntosh states: 'The impact of the changed status was immediate and profound ... By becoming an independent school, Gäwa has accessed over 320 times the level of funding for infrastructure that it received as a government remote school, not "special" funding, but "normal" government funding. ${ }^{17}$

Guthadjaka proceeded to refashion her relationship to the school and the children she saw as her responsibility. She became the school's cultural advisor, running classes to teach the children Yolngu principles of learning. Bilingual education and two-way learning became the foundation for the new school. Against a background of low attendance at larger schools in larger centres such as Galiwin'ku, at the Gäwa School, attendance rates are high. Of the 50 students on the roll, 80 per cent regularly attend school. This is in comparison with average school attendance rates in Northern Territory Emergency Response (NTER) communities, which fell from 62.1 per cent in November 2009 to 56.5 per cent in November 2010. ${ }^{18}$

In her role as a Yolngu researcher, Guthadjaka has developed strong research, teaching and consultancy links with Charles Darwin University. Guthadjaka's

\footnotetext{
15 McIntosh, 'Build a Future for Our Children'.

16 'This is Gotha's Vision'.

17 Ibid.

18 'Children of the Intervention', UN Conference on the Rights of the Child, www.concernedaustralians. com.au/media/.
} 
teaching leadership role within the wider Australian community and the outside world includes her innovative 'Teaching from Country' classes, which she conducts through Charles Darwin University. ${ }^{19}$ Her classes are conducted on Skype from her Gäwa homeland. In December 2011, she visited her classes at Tokyo University with a delegation from Charles Darwin University.

In her role of political advocate for the rights of Yolngu people, Guthadjaka has travelled widely. In October 2011 she presented a report at a UN conference on the rights of the child in Geneva with Yirrkala woman leader Djapirri Mununggirritj. Their talk was simultaneously translated into many languages. Guthadjaka told Gwenda they received strong support from the audience and the UN executive. In contrast, there is not enough support from the Australian population and little interest from Australian governments.

In the 'Children of the Intervention' report, they talked about their fears for the children affected by the intervention legislation in the Northern Territory:

We fear for their future, for their ability to learn to walk in two worlds, to obtain an education and a job. We fear for their health and their general well-being. But most of all, we fear that these recent changes [NTER legislation] will lead to the loss of our land, our culture and our language. ${ }^{20}$

Conditions of overcrowding and unsafe housing put children's health at risk. High costs for basic foods lead to high rates of malnutrition and illnesses usually seen in Third World countries. Studies have shown that homelands are safer and healthier places for children to live, but the Federal Government plans to reduce financial support to homelands rather than increase it.

Guthadjaka questioned the allocation of teachers to the 45 Homeland Learning Centres in the Northern Territory. 'Why is it', she asked, 'that some children have a qualified teacher for only two or three days each week when all children have a right to a full-time education?' She also expressed concern about the removal of the bilingual education program from NT schools. This, she believes, is the main cause of falling attendance rates. ${ }^{21}$ In the past two years, the NT Government has stipulated that there must be four hours of English teaching per day, thus effectively sidelining bilingual teaching. Guthadjaka stated that ' $[\mathrm{b}]$ ilingual learning programs recognise the importance of gaining competence in the child's first language, before introducing a second language'. She referred to the NT Government's current draft proposal to allow a modified reintroduction

19 Guthadjaka's work includes: 'Teaching when nothing is lying around'; and consultancy contributions to gambling and gambling-related harm, sustainable housing, gifted and talented children, maths as a cultural practice, and computers at Gäwa Homeland Centre. See www.cdu.edu.au/yaci.

20 Ibid.

21 Ibid. 
of the program to some schools as 'a compromise policy that fails at every level to commit to a successful re-introduction of bilingual learning'. Guthadjaka is a strong advocate for bilingual education and the acknowledgment of the special physical needs of remote settlements. ${ }^{22}$

In her role as a leader in bilingual education advocacy, Guthadjaka has presented at conferences on bilingual education, including the Building Literate Nations National Forum in 2010. She has written and published several Warramirri stories for children. Now she is exploring other means of preserving one of the two Warramirri languages that are at risk of extinction. Her new project will draw on interviews and stories gathered over many years from Warramirri speakers of this dialect.

Guthadjaka sees her life as one of vision and service to her people. For Guthadjaka, it is necessary to have a vision. 'Without a vision we cannot go forward, we can only see a fog that makes us stop.' Guthadjaka's vision makes her 'excited and energetic' ${ }^{23}$ Her leadership and participation in the processes of democratic action in local, territory and international contexts are firmly based in her Yolngu cultural beliefs and processes. To understand her vision and work, we must step outside our Western academic framework and look the world from a Yolngu epistemology.

When Guthadjaka was talking to Gwenda about the importance of a vision, she referred to a Warramirri story. ${ }^{24}$ This story follows the passage over country by some dogs. At one stage they encounter a fog, and the dogs react in different ways. Some are frightened and turn back; some cannot see the way ahead and stay where they are. But there are some who have a vision of what is ahead and keep going.

Guthadjaka reviewed this chapter and she gave us instructions on what to say in this section. She talked about God and His relationship to her work. God existed in Guthadjaka's Yolngu world long before the introduction of Christianity. ${ }^{25}$ She acknowledges that to a Western mindset this is not easily understood. Guthadjaka believes God has been fighting for her and her work. She believes God is sending her a message and that people with good heart will see and appreciate the message.

It is the Yolngu way to seek understanding and consensus, not confrontation or fighting. Guthadjaka explained that 'The Children of the Intervention'

22 Ibid.

23 Private communication between Gwenda and Guthadjaka, 14 November 2011.

24 Ibid.

25 See also Djiniyini Gondarra, 'Through Similar Journeys Comes Revelation', Generation 3(1) (April 1992): 20-3. Gondarra, Elcho Island leader, theologian and minister, wrote about his grandfather's travels across country and his awareness that there was a greater spirit behind the land and the Dreaming. 
document she presented at the United Nations was not an attempt to fight the Government and its Indigenous affairs policies and practices, but to 'put it like a truth' so that they will see. Guthadjaka respects the Government and its position in Australian society. She says, '[i]t is not my part to challenge the government', only to put the issues on the table for people to see. ${ }^{26}$

\section{Joanne Garngulkpuy}

Joanne Garygulkpuy is a Go Golpa Wangurri elder, an experienced teacher and social researcher. She lives at the main township on Elcho Island, Galiwin'ku, where she was born, grew up and went to school. She went to secondary school at Nhulumbuy and later to Batchelor College, where she graduated with a certificate in teaching. Later she went on to complete a graduate diploma in teaching and a graduate certificate in education administration.

Garngulkpuy taught at Shepherdson College and as a homeland centre teacher. She rose to the position of executive teacher, administration, and worked in the administration of the homeland schools. Her work overlapped with Guthadjaka's when she visited Gäwa for one or two days a week and assisted her in the development of stories for the children. By 2000 she was becoming worried about the future of the children, and the way in which they were being taught at the college. She saw the need for foundational work at a younger level, a need to explore Yolngu ways of teaching and learning and the need for these processes to be reinvigorated in the community.

With the establishment of the Yalu Marnggithinyaraw Centre at Galiwin'ku, Garngulkpuy saw a new role and direction for her work. In 2001 she resigned from the school and was appointed supervisor of the Yalu Marnggithinyaraw project and chief investigator of the Cooperative Research Centre for Aboriginal and Tropical Health (CRCATH) funded project 'Yolngu Theories of Transformation: The Yalu' Story'. For many years she has been the co-coordinator of the centre. The Yalu Marnggithinyaraw Centre is a foundational women's centre in the revival of Yolngu nurturing and learning in the community. 'Yalu Marnggithinyaraw' means a nest or womb, a nurturing place that starts at the beginning of life, so that all Yolngu children know who they are and who they relate to: the roles and responsibilities that all Yolngu share from birth to the grave.

Garngulkpuy has guided and mentored numerous research projects, all with links to the centre and its work. She was associate investigator of the Psychosocial Impact Indicators SCRIF funded project. ${ }^{27}$ She helped develop the

26 Private communication, 14 November 2011.

27 States/Commonwealth Research Issues Forum (SCRIF). 
Yothu Yindi school curriculum for the local primary school, and was involved in collaborations with the Collaborative Research Centre (CRC) for Aboriginal and Tropical Health, the Menzies School of Health Research and the Northern Territory University.

Garngulkpuy's clan leadership can be seen in her commitment to learn about and document Wangurri stories. In her chapter 'Garmak Gularriwuy, Gularri Water' based on an interview with her father, Buthimay, Garngulkpuy explains the water story that is fundamental to Wangurri roles and responsibilities in Yolngu society. ${ }^{28}$ The story traces the source of the water through its pathway to the sea. The Wangurri water source is at a place on Dhalinybuy, in North-East Arnhem Land, about 1.5 hours' south-west of Nhulunbuy. The source contains the 'learning and teaching methodology, confidence research ... that is its home'.

When the water wells up inside Wangurri country, it starts to flow 'and it talks - 'gapu dhä-rirrakaymirri' - water with sound in its mouth-'agreeing, negotiating, consulting, stating and empowering'. 'Dhuwandja mayali' yunhi yolnuy dhu marrtji raypirri'yun wäna rom larakam dhunupayam' - This means that when Yolyu advise and admonish each other the land tells the law straight. ${ }^{29}$

As part of her social leadership supporting Territory-wide programs, Garngulkpuy has been a member of the Council for Aboriginal Alcohol Program Services Incorporated for many years. In 2007-08 she was chair of the council, and from 2008 to 2011 she was secretary of this organisation. As a member of a study group, Garngulkpuy interviewed members of her community who were living on Larrakia land in Darwin. Many of these people were drinkers and the study tried to explain why they were living this way, with the eventual aim of encouraging them to return to their community. ${ }^{30}$ This work developed into ongoing programs talking to people, taking them to hospital and encouraging them to return home. There is now an outreach centre in Darwin and two houses for 'long-grass' people in nearby Palmerston. Garjgulkpuy also ran workshops for leaders from the Tiwi Islands, Groote Eylandt and Maningrida to help them reconnect with 'long-grass' people from their communities. She also worked as a consultant to programs on 'gambling and gambling-related harm' and the 'gifted and talented children' research.

28 Timothy Buthimang, talking to his daughter Garngulkpuy and his sister Lisa Walpulay, at the Dingu garden, Galiwin'ku, February 2008, Joanne Garngulkpuy, trans. 'GARMAK GULARRIWUY Gularri Water', Learning Communities: International Journal Of Learning in Social Contexts 2 (2010): 38-47. http://www.cdu. edu.au/centres/spill//journal/LC_Journal_Issue2_2010.pdf.

29 Joanne Garygulkpuy, 'GARMAK GULARRIWUY', 39. Joanne's other published chapters include: 'Yolyu Balandi watanumirri'; 'The Yolyu Child's Pathway'; 'Methodology for Yolyu Research'; and 'Bundurrpuy', elicited from Wapiriny and 'Teaching from Country - Learning by the Ancient Hearths'.

30 Maypilama, Garngulkpuy, Michael Christie, John Greatorex and Jocelyn Grace, Yolngu Longrassers on Larrakia Land, August 2004, http://learnline.cdu.edu.au/yolngustudies/docs/Longgrass_report.pdf. 
Garngulkpuy's advocacy for the adoption of Yolngu processes of governance has elicited interest and acceptance in academic circles. 'Yolyu Balandi watajumirri' is now used in Australian and North American universities as part of the curriculum and as the basis for workshops on Indigenous governance. It deals with governance within a Yolngu context following Yolngu rules of engagement. ${ }^{31}$

Garjgulkpuy also wants government and political circles to think about, see and support Yolngu ideas on governance. The Government needs to see where Yolngu are coming from; this would help them to understand the people. There should be less of, in her words, 'visits, visits, visits', and more talking, to help them understand the actual processes of Yolngu governance; to try to work out things that can operate and help support Yolngu governance. The Government needs to accept that
Yolngu are human, people with different governance who have something to teach them. If they learn some of the inside part, what are some of the ways of governance, then Yolngu and government can work together to develop more plans and programs which will support Yolngu governance. $^{32}$

This would lead to better governance and better outcomes for programs for the people and the Government.

Gwenda and Garngulkpuy worked together in 2010-11 on an Australian Institute of Aboriginal and Torres Strait Islander Studies (AIATSIS) Research Grant project called 'Remembering Mission Time'. Gwenda was impressed by her strong commitment to exploring the past with the aim of educating the children on what the Yolngu could, and did, do in mission times; and seeking guidance for how things could be done in the future. When they presented papers at conferences in Canberra and Melbourne in 2011, Garngulkpuy spoke strongly about the situation on the island then and now:

When I was growing up in the Yolngu rom [law] I was feeling strong and I had strong belief and values and there was encouragement and support from my own people. I was loved by all of them. I had a lot of discipline from my whole integrated family. This made me go to school every day to learn about western knowledge. I was motivated because it was a new thing. In mission times there was everyone supporting the children, now days it's only the mother and father.

31 Joanne Garngulkpuy, 'Yolyu Balandi watayumirri', 32-37.

32 Private conversations between Gwenda and Garngulkpuy, 2012. 
I need to know why children are not going to school today, why children are getting worse and [I wonder] what is the difference between the introduction of western knowledge in mission times and what teachers are teaching today. What has changed and why? Is it the parents or is it the government or is it the curriculum? What were the parents doing in the mission times? They said school was important. There are roles and responsibilities being taken away today.

In mission times the fire was in the middle and we were all around the fire feeling good, talking about things. Today the fire is going out, I am feeling cold and isolated. People are fighting with each other and bad is good and good is bad. ${ }^{33}$

On her return to Galiwin'ku, Garngulkpuy used her knowledge from the project to run two workshops, illustrating how the lessons from the past could be used in the present. The photographs and films from the time were used to show the work the Yolngu did in the mission time: the operation of the gardens, which supplied good, fresh food to the people, the fishermen and women who supplied fish for the community, the builders and roadworkers. There were discussions on the work ethic of the Yolngu and how this contributed to feelings of meaning and self-worth.

At Galiwin'ku, Garngulkpuy is heavily involved in community activities. She is often called upon to represent the Wangurri clan with her father and respected elder, Buthiman. She sees it as her duty to uphold Yolngu values and responsibilities and to teach and encourage others to do the same. Garngulkpuy is clear-thinking and positive, allowing for all clan representatives to have their say and trying to gain consensus amongst them about important processes.

Garngulkpuy works as an administrator and teacher in the programs the Yalu Centre now runs: Family as First Teachers (with the Red Cross), including a significant component of teaching using Yolngu methodology, a Community Development Employment Projects (CDEP) teaching program and a chronic diseases program (with the Menzies School of Health). All the programs are short term, and negotiations are continually required to maintain and introduce new programs. Garngulkpuy is always looking for new enterprises, ways of reaching out to the community, running programs for children and adults, and educating the wider Australian community beyond the confines of the island. There is an urgent need for a new building for the centre, which has been housed in a small discarded school portable since its inception.

33 Joanne Garngulkpuy, AIATSIS Conference Canberra, 19 September 2011; and OHHA Conference, Melbourne, 8 October 2011. 
Guthadjaka and Garjgulkpuy are strong leaders who take their roles in the democratic processes in their communities and the wider Australian society very seriously. As good leaders, they are concerned to encourage and mentor others to become leaders and take over duties when required. As Huggins notes: 'It's a very Aboriginal thing to do, to give younger people greater responsibilities within the community as they become able to take those responsibilities on.' Often on Elcho Island there is an overlap between civic and clan leadership and succession plans. This ensures that both clan and civic responsibilities are developed. Guthadjaka took her granddaughter to Geneva with her; Garjgulkpuy is encouraging a close relative to take on more responsibilities at the Yalu Centre. Women from other clans who show interest and dedication are also being nurtured at the centre. While the future of the children on Elcho Island is still precarious, Indigenous women's leadership in democratic processes seems assured.

\section{References}

Buthimang, Timothy. Talking to his daughter Garngulkpuy and his sister Lisa Walpulay, at the Dingu garden, Galiwin'ku, February 2008, Joanne Garngulkpuy, trans. 'GARMAK GULARRIWUY Gularri Water', Learning Communities: International Journal of Learning in Social Contexts 2 (2010): 38-47. http://www. cdu.edu.au/centres/spill//journal/LC_Journal_Issue2_2010.pdf.

'Children of the Intervention.' UN Conference on the Rights of the Child. www. concernedaustralians.com.au/media/.

'Computers at Gäwa Homeland Centre.' http://www.cdu.edu.au/centres/aflf/.

Gondarra, Djiniyini. 'Through Similar Journeys Comes Revelation.' Generation 3(1) (April 1992): 20-3.

Garngulkpuy, Joanne. 'GARMAK GULARRIWUY' (2010): 38-47. Learning Communities: International Journal of Learning in Social Contexts 2. http:// www.cdu.edu.au/centres/spill//journal/LC_Journal_Issue2_2010.pdf.

Garngulkpuy, Joanne. 'Yolyu Balandi watayumirri', (2010): 32-37. Learning Communities: International Journal of Learning in Social Contexts 2. http:// www.cdu.edu.au/centres/spill//journal/LC_Journal_Issue2_2010.pdf.

Huggins, Jackie. 'Indigenous Women and Leadership - A Personal Reflection.' Indigenous Law Bulletin 6(1) (2005): 5-7. 
McIntosh, Ian. 'Build a Future for Our Children: A Case Study of Institutional Discrimination in the Northern Territory of Australia.' 2009. http://www. culturalsurvival.org.au/docs/Case \%20Study \%20-\%20Building \% 20a \% 20 Future\%20for\%20our\%20children.pdf.

Maypilama, Garngulkpuy, Michael Christie, John Greatorex and Jocelyn Grace. Yolngu Longrassers on Larrakia Land, August 2004. http://learnline.cdu.edu. au/yolngustudies/docs/Longgrass_report.pdf.

Sinclair, Amanda. Leadership for the Disillusioned: Moving Beyond Myths and Heroes to Leading that Liberates. Sydney: Allen \& Unwin, 2007. 
This text taken from Diversity in Leadership: Australian women, past and present, edited by Joy Damousi, Kim Rubenstein and Mary Tomsic, published 2014 by ANU Press, The Australian National University, Canberra, Australia. 